\title{
MENINGKATKAN KETERAMPILAN MENULIS PUISI BEBAS MELALUI MEDIA GAMBAR PADA SISWA KELAS VII MTSN SEI PIMPING KECAMATAN TANJUNG KABUPATEN TABALONG
}

Irni Cahyani dan Endang Sulistyowati

\author{
Pendidikan Bahasa dan Sastra Indonesia \\ STKIP PGRI Banjarmasin
}

Jalan Sultan Adam, Komplek H. Iyus, No. 18 RT.23 Banjarmasin, Kalimantan Selatan. Kode pos 70121 email: irnicahyani@stkipbjm.ac.id

\begin{abstract}
Abstrak
Penelitian ini dilaksanakan karena kemampuan siswa dalam menulis puisi bebas pada kelas VII MTsN Sei Pimping Kecamatan Tanjung Kabupaten Tabalong masih belum sesuai dengan harapan. Masih ada yang dibawah KKM yaitu 75. Tujuan penelitian ini adalah mendeskripsikan peningkatan keterampilan menulis puisi bebas melalui media gambar pada siswa dan memaparkan aktivitas guru dan siswa kelas VII MTsN Sei Pimping Kecamatan Tanjung Kabupaten Tabalongdalam pembelajaran menulis puisi bebas, melalui penggunaan media gambar dan mengungkapkan respons siswa dalam pembelajaran menulis puisi bebas melalui penggunaan media gambar. Penelitian ini dirancang melalui pendekatan penelitian kualitatif dengan menggunakan metode tindakan kelas.

Hasil penelitian ini menunjukkan bahwa penggunaan media gambar dapat meningkatkan kemampuan menulis puisi bebas pada siswa kelas VII MTsN Sei Pimping Kecamatan Tanjung Kabupaten Tabalong. Hal ini dapat dibuktikan bahwa terjadi peningkatan kemampuan menulis puisi bebas dari siklus I dan siklus II, siklus I pertemuan I rata-rata 79 denganketuntasan klasikal 50\% meningkat pada pertemuan 2 menjadi 83 dengan ketuntasan klasikal 70\%. Pada siklus II pertemuan I rata-rata 94 dengan ketuntasan klasikal 85\% meningkat pada pertemuan 2 menjadi rata-rata 96 dengan ketuntasan klasikal 95\%. Melalui penggunaan media gambar dapat meningkatkan aktivitas guru dengan kategori sangat baik, dan aktivitas siswa dengan kategori sangat aktif.Respon siswa kelas VII MTsN Sei Pimping Kecamatan Tanjung Kabupaten Tabalong terhadap pembelajaran menulis puisi bebas melalui penggunaan media gambar. Hal ini dapat terlihat dari sebagian besar siswa menganggap media gambar dapat memudahkan mereka dalam menyimak, serta belajar mengemukakan pendapat melalui persentase dan juga hal yang terpenting yaitu pembelajaran menjadi menyenangkan.
\end{abstract}

Kata kunci: keterampilan menulis, puisi

\section{Pendahuluan}

Keterampilan berbahasa biasanya mencakup empat segi/komponen, yaitu keterampilan menyimak (listening skills), keterampilan berbicara (speaking skills), keterampilan membaca (reading skills), keterampilan menulis (writing skills). Setiap keterampilan itu erat sekali hubungannya dengan ketiga keterampilan lainnya dengan cara yang beraneka ragam. Dalam memperoleh keterampilan berbahasa, biasanya melalui suatu hubungan urutan yang teratur.Keterampilan menulis merupakan suatu keterampilan berbahasa yang dipergunakan untuk berkomunikasi secara tidak langsung, tidak secara tatap muka dengan orang lain. 
Pembelajaran merupakan suatu proses dalam arti sebagai kegiatan yang disadari dan terencana. Jadi, kegiatan pembelajaran bukan suatu proses yang berjalan alami dan bersifat otomatis. Segala tindakan yang dilakukan, baik guru maupun siswa, senantiasa direncanakan dan diperhitungkan sedemikian rupa. Rencana pembelajaran sendiri harus dirumuskan secara sistematis, terutama oleh pihak guru selaku pengelola kegiatan pembelajaran, mulai dari penyusunan program pembelajaran sampai dengan pelaksanaan evaluasinya (Jamaluddin, 2003: 23).Menurut hasil penelitian, masih banyak sekolah yang bermasalah dalam pembelajaran menulis puisi. Faktor masalah tersebut berasal dari guru, dan siswa. Faktor yang berasal dari guru, karena belum menggunakan media yang tepat dalam pembelajaran menulis puisi bebas, berakar dari masalah itulah, maka siswa kurang tertarik dan tidak termotivasi dalam pembelajaran menulis puisi. Oleh karena itu, peneliti ingin mencoba menggunakan media gambar sebagai media pembelajaran sebagai menulis puisi bebas.

Penggunaan media gambar merupakan salah satu cara membantu siswa lebih memahami untuk meningkatkan keterampilan menulis puisi. Media gambar dapat berupa gambar pemandangan alam, pemandangan laut, pemandangan pantai, pasar, pemukiman penduduk dan lain sebagainya. Dengan bantuan media gambar, imajinasi murid akan muncul lebih baik, sehingga mereka dapat berkreasi dalam membuat karangan.Tujuan penelitian adalah mendeskripsikan kemampuan menulis puisi bebas melalui media gambar pada siswa kelas VII MTsN Sei Pimping Kecamatan Tanjung Kabupaten Tabalong.

Mendeskripsikan aktivitas guru dan siswa dalam proses pembelajaran menulis puisi bebas melalui media gambar dan mendeskripsikan penggunaan media pembelajaran menulis puisi bebas melalui media gambar.Keterampilan menulis atau dengan sebutan menulis merupakan suatu bentuk keterampilan berbahasa di samping ketiga keterampilan yang lain, yaitumenulis ialah menurunkan atau melukiskan lambang-lambang grafik yang menggambarkan suatu bahasa yang dipahami oleh seseorang, sehingga orang-orang lain dapat membaca lambang-lambang grafik itu. Tujuan penulis adalah responsi atau jawaban yang diharapkan oleh penulis akan diperolehnya dari pembaca.Secara garis besar, penulis dengan tulisannya berupaya untuk memberikan atau menyampaikan segala bentuk dan macam informasi kepada pembaca. Tentu saja penulis dengan karyanya itu berharap, agar pembaca menerima semua yang diungkapkannya sebagai masukan yang berharga.Dengan demikian, kita tidak bisa memisahkan antara tujuan menulis dengan tujuan penulis itu sendiri. Oleh karena itu, sudah selayaknya penulis membuat atau menyusun tulisannya dengan bahasa yang mudah dipahami, jelas dan penyajiannya yang sistematis atau teratur (Musaba, 2011:4).Kata mediaberasal dari bahasa Latin yaitu medius yang secara harfiah berarti tengah perantara atau pengantar. Dalam bahasa Arab, media adalah perantara atau pengantar pesan dari pengirim kepada penerima pesan (Arsyad, 2002: 3). 
Dalam proses pembelajaran, hadirnya media sangat diperlukan, sebab mempunyai peranan besar yang berpengaruh terhadap pencapaian tujuan pembelajaran. Hal ini, dikarenakan belajar tidak selamanya hanya bersentuhan dengan hal-hal konkret, baik dalam konsep maupun faktanya. Bahkan dalam realitasnya belajar seringkali bersentuhan dengan hal-hal yang bersifat kompleks, maya dan berada di balik realitas. Oleh karena itu, media memiliki andil untuk menjelaskan hal-hal yang abstrak dan menunjukkan hal-hal yang tersembunyi. Ketidakjelasan atau kerumitan materi pembelajaran dapat dibantu dengan menghadirkan media sebagai perantara. Bahkan dalam hal-hal tertentu media dapat mewakili kekurangan guru dalam mengkomunikasikan materi pembelajaran.

Menulis puisi adalah sebagai bentuk menumpahkan isi hati, batin dan perasaan, maka beruntai dan beruntun kata akan terbentuk. Isi hati didapat dari pengalaman hidup tentang masa lalu, masa sekarang bahkan beberapa detik yang lalu, hingga tertuang dalam tulisan dan kemudian diungkapkan. Pengalaman seperti ini hampir dilakukan oleh semua orang, baik pemula maupun mereka yang sudah berpengalaman dalam menulis puisi. Ada yang menggugah perasaan sang penulis, dan ada juga yang tidak sama sekali (Ghani. 2013: 1). Menulis puisi adalah bentuk karya sastra yang menggunakan kata-kata yang indah dan padat makna.Berdasarkan urutan perkembangannya, puisi dapat diklasifikasikan sebagai berikut yaitu puisi lama, yang termasuk ke dalam puisi lama adalah mantra, pantun kilat, gurindam, syair. Dalam puisi ini, berbagai ikatan yang berlaku dalam puisi lama benar-benar dipentingkan. Sedangkan puisi modern tidak lagi mengutamakan bentuk fisik, melainkan kepada bentuk makna. Dengan kata lain, pada puisi modern, aspek isi lebih diutamakan dari pada aspek bentuk(Rosdyanto, 2007: 283).

Pada umumnya kemampuan menulis puisi bebas pada siswa kelas VII MTsN Sei Pimping Kecamatan Tanjung, masih rendah. Pengajaran dengan media gambar dapat meningkatkan kemampuan menulis puisi bebas pada siswa MTsN Sei Pimping.Berdasarkan kerangka berpikir tersebut, maka hipotesis tindakan dapat dirumuskan sebagai berikut: jika digunakan media gambar, maka akan meningkatkan keterampilan menulis puisi bebas pada siswa kelas VII MTsN Sei Pimping Kecamatan Tanjung Kabupaten Tabalong.

\section{Metode}

Penelitian Tindakan Kelas ini dilaksanakan empat kali pertemuan.Penelitian Tindakan Kelas adalah suatu rangkaian langkah yang terdiri atas empat tahap, yakni perencanaan, tindakan, pengamatan, dan refleksi.Subjek yang menjadi penelitian ini adalah siswa kelas VII MTsN Sei Pimping Kecamatan Tanjung Kabupaten Tabalong dengan jumlah siswa sebanyak 24 orang yang terdiri dari 10 orang laki-laki dan 14 orang perempuan. Lokasi penelitian ini dilakukan di MTsN Sei Pimping yang beralamat di DesaSei Pimping KecamatanTanjung Kabupaten Tabalong. Dalam Penelitian Tindakan Kelas, ada tiga unsur atau konsep, yaitu sebagai berikut:Penelitian adalah 
aktivitas mencermati suatu objek tertentu melalui metodologi ilmiah dengan mengumpulkan datadata dan dianalisis untuk menyelesaikan suatu masalah.Tindakan adalah suatu aktivitas yang sengaja dilakukan dengan tujuan tertentu yang berbentuk siklus kegiatan dengan tujuan untuk memperbaiki atau meningkatkan mutu atau kualitas proses belajar-mengajar.Kelas adalah sekelompok siswa dalam waktu yang sama menerima pelajaran yang sama dari seorang guru (Kunandar, 2011: 45).Penelitian Tindakan Kelas atau PTK (Classroom Action Research) memiliki peranan yang sangat penting dan strategis untuk meningkatkan mutu pembelajaran apabila diimplementasikan dengan baik dan benar. Pihak yang terlibat dalam PTK mencoba dengan sadar mengembangkan kemampuan dalam mendeteksi dan memecahkan masalah-masalah yang terjadi dalam pembelajaran di kelas melalui tindakan bermakna yang diperhitungkan dapat memecahkan masalah atau memperbaiki situasi dan kemudian secara cermat mengamati pelaksanaannya untuk mengukur tingkat keberhasilannya.

Rancangan penelitian dalam Penelitian Tindakan Kelas ini terdiri dari dua siklus, dan setiap siklus terdiri atas dua kali pertemuan. Adapun rancangan penelitian dapat dijelaskan sebagai berikut:Perencanaan Tindakan yaitu meminta izin penelitian kepada kepala sekolah dan guru bahasa Indonesia yang bersangkutan, menyusun Rencana Pelaksanaan Pembelajaran (RPP),menyiapkan media pembelajaran dalam menulis puisi bebas, merancang pembelajaran menulis puisi bebas dengan media gambar dan menyiapkan instrumen pembelajaran (pedoman observasi, LKS, dan lembar tes).

Pelaksanaan Tindakan Kelas Siklus I terdiri dari 2 kali pertemuan dengan kegiatan antara lain: Pertemuan pertama, guru menyampaikan tujuan pembelajaran dan memberikan informasi tentang materi dan media yang akan digunakan dalam proses belajar mengajar.Kemudian guru menyampaikan materi pembelajaran.Setelah itu, guru meminta siswa membacakan puisi yang dibagikan. Lalu guru meminta siswa menulis puisi bebas dengan media gambar.Setelah itu, siswa mengumpulkan hasil menulis puisi bebas dengan media gambar. Kemudian, guru bersama siswa menyimpulkan pembelajaran yang telah dipelajari. Pertemuan kedua yaitu guru menyampaikan tujuan pembelajaran dan memberikan informasi tentang materi dan media yang akan digunakan dalam proses belajar mengajar.Berikutnya guru menyampaikan materi pembelajaran. Setelah itu, guru meminta siswa membaca puisi bebas dengan media gambar yang dibagikan.Kemudian, guru meminta siswa menulis puisi bebas dengan media gambar. Setelah itu, siswa mengumpulkan hasil menulis puisi bebas dengan media gambar.Kemudian, guru bersama siswa menyimpulkan pembelajaran yang telah dipelajari.

Tahap Observasi dan Evaluasi 
Tahap ini dilakukan dengan mengamati aktivitas-aktivitas pada saat proses pembelajaran menggunakan media gambar. Alat yang digunakan dalam melakukan kegiatan observasi ini berupa lembar observasi. Observasi yang dilakukan pada proses kegiatan belajar-mengajar terdiri dari:

Observasi aktivitas yang dilakukan guru danobservasi aktivitas yang dilakukan siswa.Melalui pengamatan, akan diketahui perubahan-perubahan yang terjadi, baik yang ditimbulkan oleh tindakan terencana maupun tidak, serta mengetahui seberapa jauh pelaksanaan tindakan yang diharapkan akan menghasilkan peningkatan yang diinginkan. Selain itu, pada akhir siklus akan dilakukan evaluasi akhir untuk mengetahui hasil pembelajaran menggunakan media gambar, apakah siswa mengerti materi-materi yang sudah diberikan guru secara keseluruhan.

Tindakan Siklus II ini sama seperti Siklus I. Siklus II juga terdiri atas tahap perencanaan, pelaksanaan, observasi dan refleksi. Siklus II ini akan dilakukan apabila indikator keberhasilan tindakan pada Siklus I belum mencapai tujuan pembelajaran yang diinginkan atau belum optimal. Data utama yang akan dikumpulkan, serta cara pengumpulan data selama pelaksanaan PTK diuraikan sebagai berikut:Teknik tes dilakukan pada akhir pembelajaran dengan tujuan untuk mengetahui sejauhmana kemampuan menulis puisi bebas menggunakan media gambar. Tes ini dilengkapi dengan format penilaian yang disesuaikan dengan kompetensi yang ingin dicapai setelah pembelajaran.

Observasi dalam kegiatan belajar mengajar dilakukan dengan tujuan untuk memperoleh gambaran, baik bersifat umum, maupun khusus yang berkenaan pembelajaran menulis puisi bebas dengan media gambar. Aspek yang diobservasi diantaranya ialah aktivitas siswa dalam belajar dan aktivitas guru dalam perencanaan dan pelaksanaan pembelajaran.Angket, yaitu untuk mengetahui respons siswa dalam pembelajaran menulis puisi bebas melalui media gambar pada siswa kelas VII MTsN Sei PimpingKecamatan Tanjung Kabupaten Tabalong.

Teknik analisis data penelitian dilakukan secara kuantitatif dan kualitatif. Analisis data kuantitatif dipakai untuk menganalisis data kuantitatif yang diperoleh dari hasil tes menulis puisi bebas dengan media gambar pada Siklus I dan Siklus II. Cara penilaian hasil belajar siswa menggunakan rumus:

\section{Skor Perolehan}

Secara individual $\quad \mathrm{N}=\mathrm{x} 100 \%$

Skor Maksimal

Jumlah Siswa yang Tuntas Belajar

Secara klasikal $\quad \mathrm{N}=\longrightarrow 100 \%$

Jumlah Skor Maksimal 
Keterangan $\mathrm{N}=$ Nilai Akhir

(Kunandar 2013: 307)

Analisis data kualitatif dipakai untuk menganalisis data kualitatif yang diperoleh dari hasil nontes yaitu observasi, dan angket. Penganalisisan data kualitatif dengan menganalisis lembar observasi yang telah diisi pada saat pembelajaran. Penilaian dilakukan dengan cara sebagai berikut:

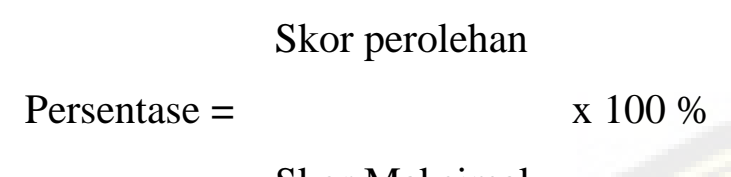

Skor Maksimal

Indikator keberhasilan dalam Penelitian Tindakan Kelas ini adalah sebagai berikut.Hasil belajar yang diharapkan secara individual adalah sesuai dengan KKM yaitu 75, sedang secara klasikal minimal 70\% siswa dinyatakan tuntas belajar.Perolehan nilai aktivitas guru dengan nilai 76-80 dengan kategori "Baik", sedangkan untuk aktivitas siswa dengan nilai 81-100 dengan kategori "Sangat Baik".Hasil angket menunjukkan sebagian besar siswa ( $\geq 80 \%)$ menunjukkan respon dengan baik terhadap pembelajaran melalui penggunan media gambar.

\section{Hasil dan Pembahasan}

Dalam pembelajaran menulis puisi bebas terdiri dari empat kali pertemuan. Pada pertemuan pertama, siswa disajikan materi tentang pengertian puisi, jenis puisi, dan langkah-langkah membuat puisi dan di setiap akhir pelajaran baik pada pertemuan pertama dan kedua dari siklus satu dan dua dilakukan tes evaluasi.

Kegiatan pendahuluan dimulai dengan guru memeriksa kesiapan siswa dengan mengisi daftar hadir dan perlengkapan belajar siswa. Guru menyampaikan apersepsi dengan cara meminta salah seorang siswa untuk membacakan contoh puisi bebas yang didengarkan oleh seluruh siswa. Guru menjelaskan secara singkat materi pokok pembelajaran, kemudian guru melanjutkan dengan menjelaskan secara singkat tujuan pembelajaran dan manfaat pembelajaran bagi kehidupan siswa.

Guru membagi siswa ke dalam 4 kelompok yang beranggotakan 6 orang. Kemudian membagikan masing-masing bahan gambar dibagikan kepada siswa yaitu gambar pemandangan dengan topik yang sama kepada siswa. Guru menjelaskan cara menulis puisi bebas dan langkahlangkah membuat puisi yang baik dan benar. Guru meminta siswa membaca bahan yang telah dibagikan. Guru memfasilitasi peserta didik dengan media gambar. Peserta didik diminta dan dibimbing menulis puisi yang terdapat dalam foto atau gambar melalui lembar kerja siswa. 
Vol.3 No.1, 1 April 2018

Kegiatan pembelajaran dilanjutkan dengan memfasilitasi peserta didik untuk menyajikan hasil kerja individual maupun kelompok.

Setelah selesai, guru memberikan umpan balik positif dan penguatan dalam bentuk lisan, tulisan, maupun hadiah terhadap keberhasilan peserta didik. Guru bersama peserta didik membuat rangkuman/kesimpulan pelajaran. Kemudian guru melakukan penilaian atau refleksi terhadap kegiatan yang sudah dilaksanakan secara konsisten dan terprogram, dilanjutkan dengan menyiapkan rencana pembelajaran pada pertemuan berikutnya.

Hasil Evaluasi Belajar Siswa

Berdasarkan evaluasi pada Siklus I yang dilakukan diakhir pelajaran setiap pertemuan, diperoleh hasil evaluasi yang tertuang pada tabel berikut.

\section{Tabel 1. Hasil Evaluasi Belajar Siswa}

\begin{tabular}{lcc}
\hline Siklus I & Nilai Rata-rata & Ketuntasan Klasikal \\
\hline Pertemuan I & 79 & $50 \%$ \\
Pertemuan II & 82 & $60 \%$ \\
\hline
\end{tabular}

Berdasarkan penilaian terhadap hasil belajar Siklus I Pertemuan pertama, dan Siklus I Pertemuan II terjadi peningkatan. Pertemuan pertama mendapat nilai rata-rata 78 sedangkan pertemuan kedua mendapat nilai rata-rata 83.

\section{Tabel 2. Hasil Observasi Aktivitas Guru}

\begin{tabular}{lcc}
\hline Siklus I & Nilai Rata-rata & Ketegori \\
\hline Pertemuan I & 79 & Baik \\
Pertemuan II & 85 & Sangat Baik \\
\hline
\end{tabular}

Aktivitas guru dalam pembelajaran Siklus I Pertemuan pertama diperoleh nilai 77 dengan kategori baik, dan pada pertemuan kedua diperoleh nilai 82 dengan kategori sangat baik.

Hasil observasi terhadap aktivitas belajar siswa pada kegiatan pembelajaran menulis puisi bebas dengan media gambar pada Siklus I diterangkan melalui tabel berikut.

Tabel 3. Hasil Observasi Aktivitas Siswa Siklus I

\begin{tabular}{lcc}
\hline Siklus I & Nilai Rata-rata & Ketegori \\
\hline Pertemuan I & 77 & Aktif \\
Pertemuan II & 82 & Sangat Aktif \\
\hline
\end{tabular}

Berdasarkan tabel 3 pada Siklus I pertemuan pertama, maka perolehan skor aktivitas siswa dalam pembelajaran, memperoleh skor 307, maka dapat dilakukan perhitungan dengan menggunakan rumus yang telah ditentukan, sehingga diperoleh nilai 77, pada kategori yang telah 
ditetapkan,termasuk pada rentang 61-80 dengan kategori “Aktif ".Pada pertemuan kedua, skor perolehan aktivitas siswa yaitu 328, maka dilakukan perhitungan dengan menggunakan rumus yang telah ditentukan, yaitu diperoleh nilai 82, sehingga kategori nilai yang telah ditetapkan masuk pada rentang nilai antara 81-100 dengan kategori "Sangat Aktif ".Berdasarkan analisis hasil belajar dan pengamatan aktivitas guru dan siswa yang diperoleh pada siklus I, maka dilakukan refleksi bersama pengamat dengan kesimpulan sebagai berikut:

Hasil belajar bahasa Indonesia siswa pada aspek menulis puisi Siklus I Pertemuan I diperoleh nilai dengan rata-rata 78,12. Secara klasikal terdapat 12 orang dari 24 siswa yang mencapai KKM atau 50\% dan sisanya 12 orang yang belum mencapai KKM yaitu 75. Sedangkan hasil belajar bahasa Indonesia Siklus I Pertemuan 2 diperoleh nilai dengan rata-rata 82,9. Secara klasikal terdapat 14 orang dari 24 siswa yang mencapai nilai KKM atau 60\%, dan sisanya 8 orang yang masih belum mencapai KKM yaitu 75 . Hasil ini juga dikaitkan dengan indikator keberhasilan belajar secara klasikal sudah memenuhi indikator keberhasilan.

Aktivitas guru dalam pembelajaran Siklus I Pertemuan I diperoleh nilai 79. Dikaitkan dengan kategori perolehan nilai yang telah ditetapkan, masuk pada rentang nilai antara 61-80 dengan kategori "baik". Sedangkan aktivitas guru dalam pembelajaran Siklus I Pertemuan 2 diperoleh nilai 85. Dikaitkan dengan kategori perolehan nilai yang telah ditetapkan, masuk pada rentang nilai antara 80-100 dengan kategori "sangat baik". Pada pertemuan berikutnya yaitu Siklus II, guru perlu meningkatkan aktivitas pada aspek pengamatan yang memperoleh skor 3 dan 2 .

Aktivitas belajar siswa Siklus I Pertemuan I diperoleh nilai 76,7 (77). Dikaitkan dengan kategori perolehan nilai yang telah ditetapkan masuk pada rentang nilai antara 61-80 dengan kategori “Aktif”. Sedangkan pada aktivitas belajar siswa pada Siklus I Pertemuan 2 diperoleh nilai (82). Dikaitkan dengan kategori perolehan nilai yang telah ditetapkan masuk pada rentang nilai antara 81-100 dengan kategori "Sangat Aktif". Pada pertemuan berikutnya (Siklus II) guru masih dapat meningkatkan aktivitas belajar siswa, diperlukan perhatian lebih kepada siswa yang memperoleh skor 1 dan 2 pada aspek-aspek pengamatan, karena siswa yang aktivitas belajarnya kurang, sudah dapat diidentifikasikan dari hasil observasi, yaitu pertemuan 1 dan 2. Memperhatikan hasil penelitian Siklus I di atas dan dibandingkan dengan indikator keberhasilan dalam penelitian ini, maka masih belum tercapai secara maksimal. Penelitian akan dilanjutkan pada Siklus II dengan memperhatikan kelemahan-kelemahan yang terjadi pada Siklus I dan dilakukan perbaikanperbaikan pada Siklus II berikutnya.

Pelaksanaan Siklus II

Pada Siklus I, indikator keberhasilan belum tercapai. Hal ini dikarenakan masih ada beberapa siswa yang kurang aktif dan kurang serius dalam pembelajaran, serta guru masih belum menguasai kelas 


\section{Tabel 4. Hasil Evaluasi Belajar Siswa Siswa Siklus II}

\begin{tabular}{lcc}
\hline Siklus I & Nilai Rata-rata & Ketuntasan Klasikal \\
\hline Pertemuan I & 94 & $85 \%$ \\
Pertemuan II & 96 & $95 \%$ \\
\hline
\end{tabular}

Berdasarkan evaluasi pada Siklus II yang dilakukan diakhir pembelajaran setiap pertemuan, diperoleh hasil evaluasi yang tertuang pada tabel tersebut..

Hasil Evaluasi Siklus II

Dari tabel dapat dilihat hasil belajar pada pertemuan pertama memperoleh nilai rata-rata 94 dengan ketuntasan klasikal 85\%.

Pertemuan kedua memperoleh nilai rata-rata 96 dengan ketuntasan klasikal 95\%

\section{Tabel 5. Hasil Observasi Aktivitas Guru}

\begin{tabular}{lcc}
\hline Siklus II & Nilai Rata-rata & Ketegori \\
\hline Pertemuan I & 91 & Sangat Aktif \\
Pertemuan II & 94 & Sangat Aktif \\
\hline
\end{tabular}

Berdasarkan tabel tersebut, maka petemuan pertama pada Siklus II, aktivitas guru memperoleh nilai 91 dengan kategori "Sangat Baik”.Pada pertemuan kedua, yaitu aktivitas guru memperoleh nilai 94 dengan kategori "Sangat Aktif".

Hasil Observasi Aktivitas Siswa

Hasil observasi terhadap aktivitas belajar siswa dalam kegiatan pembelajaran pada Siklus II dapat diterangkan sebagai berikut

\section{Tabel 6. Hasil Observasi Aktivitas Siswa Siklus II}

\begin{tabular}{lcl}
\hline Siklus I & Nilai Rata-rata & Kategori \\
\hline Pertemuan I & 85 & Sangat Aktif \\
Pertemuan II & 97 & Sangat Aktif \\
\hline
\end{tabular}

Dari perolehan skor pertemuan pertama pada Siklus 2 ini, maka aktivitas siswa diperoleh skor 340, sehingga dapat dilakukan perhitungan dengan menggunakan rumus yang telah ditentukan yaitu diperoleh nilai 85, maka kategori perolehan nilai masuk pada rentang 81-100 dengan kategori "Sangat Aktif".

Pada pertemuan kedua, yaitu aktivitas siswa memperoleh skor 389, sehingga dapat dilakukan perhitungan dengan menggunakan rumus yang telah ditentukan, maka diperoleh nilai yaitu 97, maka perolehan nilai masuk pada rentang antara 81-100 dengan kategori "Sangat Aktif". 
Tabel 7.Perbandingan Hasil Belajar Siswa Siklus I dan Siklus II

\begin{tabular}{lcc}
\hline Siklus I & Nilai Rata-rata & Klasikal \\
Pertemuan I & 79 & $50 \%$ \\
Pertemuan II & 85 & $60 \%$ \\
\hline Siklus II & Nilai Rata-rata & Klasikal \\
Pertemuan I & 94 & $85 \%$ \\
Pertemuan II & 96 & $96 \%$ \\
\hline
\end{tabular}

Berdasarkan perbandingan hasil belajar bahasa indonesia pada aspek menulis puisi bebas di atas, terjadi peningkatan antara siklus I dan siklus II, sehingga dapat dikatakan bahwa melalui penggunaan media gambar dapat meningkatkan hasil belajar menulis puisipada siswa kelas VII MTsN Sei Pimping Kecamatan Tanjung Kabupaten Tabalong.

Peningkatan hasil belajar terjadi seiring dengan peningkatan aktivitas belajar siswa dari Siklus I Pertemuan 1 sampai Siklus II Pertemuan 2. Keberhasilan penelitian ini juga sejalan dengan pengertian pendidikan. Pendidikan adalah usaha sadar dan terencana untuk mewujudkan suasana belajar dan proses pembelajaran, agar peserta didik secara aktif mengembangkan potensi dirinya untuk memiliki kekuatan spiritual keagamaan, pengendalian diri, kepribadian, akhlak mulia, serta keterampilan yang diperlukan dirinya, masyarakat, bangsa dan negara.

Ditinjau dari indikator keberhasilan hasil belajar, maka dapat dikatakan bahwa hasil penelitian pada indikator keberhasilan hasil belajar telah tercapai dengan baik, dan hipotesis yang berbunyi “jika digunakan media gambar, maka kemampuan menulis puisi pada siswa kelas VII MTsN Sei pimping Kecamatan Tanjung Kabupaten Tabalong dapat diterima.

Aktivitas Guru dan Siswa

Aktivitas guru dalam melaksanakan pembelajaran bahasa Indonesia pada aspek menulis puisi menggunakan media gambar di kelas VII MTsN Sei pimping Kecamatan Tanjung Kabupaten Tabalong pada Siklus I dan Siklus II dapat dilihat sebagai berikut.

Tabel 8. Perbandingan Nilai Aktivitas Guru Siklus I dan Siklus II

\begin{tabular}{lcc}
\hline Siklus I & Nilai Aktivitas Guru & Kategori \\
Pertemuan I & 79 & Sangat Baik \\
Pertemuan II & 85 & Sangat Baik \\
\hline Siklus II & Nilai Aktivitas Guru & Kategori \\
Pertemuan I & 91 & Sangat Baik \\
Pertemuan II & 94 & Sangat Baik
\end{tabular}


Berdasarkan hasil perbandingan hasil penilaian aktivitas guru diatas, terjadi peningkatan antara Siklus I dan Siklus II, sehingga dapat dikatakan bahwa guru dapat melaksanakan pembelajaran bahasa Indonesia pada aspek menulis puisi bebas melalui penggunaan media gambar di kelas dengan sangat baik. Peningkatan yang terjadi menunjukkan bahwa penggunaan media gambardapat meningkatkan aktivitas guru dalam melaksanakan pembelajaran bahasa Indonesia pada aspek menulis puisi bebas. Keberhasilan aktivitas guru dalam melaksanakan pembelajaran bahasa Indonesia pada aspek menulis puisi pada peristiwa/gambar yang diberikan.

Aktivitas siswa dalam pembelajaran bahasa Indonesiapada aspek menulis puisi bebas melalui penggunaan media gambar pada kelas VII MTsN Sei Pimping Kecamatan Tanjung Kabupaten Tabalong pada Siklus I dan Siklus II dapat dilihat sebagai berikut:

\section{Tabel 9. Perbandingan Nilai Aktivitas Siswa Siklus I dan Siklus II}

\begin{tabular}{lcc}
\hline Siklus I & Nilai Aktivitas Siswa & Kategori \\
Pertemuan I & 79 & Aktif \\
Pertemuan II & 82 & Aktif \\
\hline Siklus II & Nilai Aktivitas Siswa & Kategori \\
Pertemuan I & 85 & Sangat Aktif \\
Pertemuan II & 97 & Sangat Aktif
\end{tabular}

Berdasarkan perbandingan hasil penelitian aktivitas siswa di atas,terjadi peningkatan dari Siklus I ke Siklus II dapat dikatakan bahwa siswa sangat aktif dalam pembelajaran bahasa Indonesia pada aspek menulis puisi bebasmelalui penggunaan media gambar pada siswa kelas VII MTsN Sei Pimping Kecamatan Tanjung Kabupaten Tabalong.

Peningkatan yang terjadi menunjukkan bahwa penggunaan media gambar dapat meningkatkan aktivitas siswa dalam pembelajaran bahasa Indonesia pada aspek menulis puisi bebas. Hasil pengamatan Siklus II menunjukkan peningkatan yang cukup signifikan. Siswa mampu menuangkan isi pikirannya dalam puisi.

Respon siswa terhadap pembelajaran menulis puisi bebas melalui penggunaan media gambar yaitu hal ini dapat terlihat dari angket, sebagian besar siswa menganggap penggunaan media gambardapat memudahkan mereka dalam pemahaman pelajaran, memudahkan mereka mengingat pelajaran, dan menyenangkan dalam proses belajar mengajar.

\section{Simpulan}

Berdasarkan hasil Penelitian Tindakan Kelas pada penjelasan sebelumnya, dapat disimpulkan bahwa dengan media gambar dapat meningkatkan kemampuan menulis puisi bebas pada siswa 
kelas VII MTsN Sei Pimping Kecamatan Tanjung Kabupaten Tabalong pada tahun pelajaran 2017/2018. Hasil ini dapat dilihat dari:

Penggunaan media gambar dapat meningkatkan kemampuan menulis puisi bebas. Hal ini dapat dibuktikan yaitu terjadi peningkatan kemampuan menulis puisi dari Siklus I dan Siklus II, Siklus I Pertemuan I dengan rata-rata 79 ketuntasan klasikal 50\% meningkat pada pertemuan 2 menjadi rata-rata 85 dengan ketuntasan klasikal 70\%. Pada Siklus II Pertemuan 1 dengan rata-rata 94 dengan ketuntasan $85 \%$ meningkat pada pertemuan 2 menjadi rata-rata 96 dengan ketuntasan klasikal 95\%.Aktivitas guru pada Siklus I diperoleh nilai (79) (Baik) dan (85) (Baik), pada Siklus II menjadi (91) ( Sangat Baik) dan (95) (Sangat Baik). Aktivitas siswa Siklus I diperoleh nilai (77) (Aktif) dan (82) (Aktif), pada Siklus II menjadi (85) Sangat Aktif dan (97) Sangat Aktif.Respon siswa kelas VII MTsN Sei Pimping Kecamatan Tanjung Kabupaten Tabalong terhadap pembelajaran menulis puisi bebas melalui penggunaan media gambar yaitu hal ini dapat dilihat sebagian besar siswa menganggap media gambar dapat memudahkan mereka dalam menulis puisi bebas, juga hal yang terpenting dalam pembelajaran yaitu menyenangkan

\section{Daftar Pustaka}

Arikunto, Suharsimi. 2010. Penelitian Tindakan Kelas. Yogyakarta: Aditya Media. . 2014. Tips Pintar PTK: Penelitian Tindakan Kelas. Jakarta: Bumi Aksara.

Arsyad, Azhar. 2002. Media Pembelajaran. Jakarta: PT Raja Grafindo Persada.

Atmono, Dwi. 2009. Panduan Praktis Penelitian Tindakan Kelas. Yogyakarta: Pelangi Aksara.

Ghani, Tajuddin Noor. 2013. Teori Menulis Puisi: Pustaka Banua.

Jamaluddin. 2003. Problematik Pembelajaran Bahasa dan Sastra. Yogyakarta: Adicita Karya Nusa.

Kunandar. 2011. Penelitian Tindakan Kelas. Jakarta: PT Raja Grafindo Persada.

2013. Penilaian Autentik (Penelitian Hasil Belajar Peserta Didik Berdasarkan Kurikulum 2013). Jakarta: PT Raja Grafindo Persada.

Mahsun. 2011. Metode Penelitian Bahasa: Tahapan Strategi, Metode, danTekniknya. Jakarta: PT. Rajagrafindo Persada.

Musaba, Zulkifli. 2011. Bahasa Indonesia untuk Mahasiswa. Yogyakarta: CV Aswaja Pressindo.

Rosdyanto dan Asep Juanda. 2007. Intisari Bahasa dan Sastra Indonesia: CV Pustaka Setia.

Tarigan, Henry Guntur. 2008. Menulis sebagai Suatu Keterampilan Berbahasa. Bandung: Angkasa.

Tarsyad, Tarman Effendi. 2012. Teori dan Sejarah Puisi Indonesia. STKIP PGRI Banjarmasin. 